\title{
Sikere; Mentawai Ancient Medicine Rituals in the Perspective of the Postmodern Era of Performing Arts
}

\author{
Hendra Nasution, S.Sn., M.Sn, Ezu Oktavianus S.Sn., M.Sn, B Ajismon Feriarno \\ Indonesia Art Institute of Padangpanjang \\ DOI: 10.29322/IJSRP.12.01.2022.p12169 \\ http://dx.doi.org/10.29322/IJSRP.12.01.2022.p12169
}

\begin{abstract}
This paper discussed about the ancient medical system of the Mentawai tribal community and find that the possibility of this system made the ritual a form of performance performed by Sikerei in the Postmodern era. In connection with this, the researcher formulates the research problem, namely how the form of the ritual, the factors that cause changes, and the impact caused by these changes. This study uses a qualitative method, which aims to understand and analyze the ancient healing rituals of the Mentawai tribe in the perspective of performing arts with a multidisciplinary approach. Data collection techniques used are observation, interviews and documentation. The results of the study indicate that the form of change leads to a shift in ritual values in Sikerei as Mentawai healers.
\end{abstract}

Index Terms- Ritual, Medicine, Sikerei, Mentawai

\section{INTRODUCTION}

$\mathrm{T}$ he Mentawai Islands are the outermost regency in West Sumatra which is located along the westernmost part of the island of Sumatra and is surrounded by the Indian Ocean. As a researcher who has come to the Mentawai Islands, the proposer sees that the influence of global cultural flows in the Mentawai Islands Regency has implications for the cultural practices of capitalism, namely the emergence of a cultural industry which refers to a shift in cultural form as a digital industry where the Mentawai tribe is only an object which is then brought out of society. The ancient healing ritual of the Mentawai Tribe "SIKEREI" is one of the cultures affected by this shift. In connection with this, the proposed research is Sikerei; The Mentawai Tribe Ancient Medicine Ritual in the Perspective of Performing Arts in the Postmodern Era will formulate a study that seeks to restore traditions that have been rooted in the customs of the Mentawai Tribe.

Sikerei is one of the traditional Mentawai community structures that play an important role. Sikerei is in charge of public health, Sikerei is in charge of finding the cause and eradicating disharmony through the ecstasy of unconscious states. This is done as if the soul had left the body. In the social structure of Sikerei's position, it is marked by the sibalubalu tattoo motif on the base of the arm. The social and belief structure concerns the function of the tattoo with the sibalubalu motif used by Sikerei. The motif is located at the base of the arm, serves as a symbol of health care for the community and this is only owned by Sikerei.

Lucky Zamzami $(2013,29)$ said that in the 1990s the development of research in the life of the Mentawai ethnic group has taken place until now, a massive and intense process of social transformation has taken place. This is closely related to the changing dynamics of the Mentawai people's lives when they interact with external spheres of power and global influence. Neglect in this context leads to a link between changes in livelihoods and production with cultural involution and its influence in the details of ritual processions. The emergence of ethnic identities, economic opportunities from tourism and new political aspirations were enthusiastically welcomed by the Mentawai community (Hammons 2010; Tulius 2012). Sikerei Research ; The Mentawai Ancient Medicine Ritual in the Perspective of Performing Arts in the Postmodern Era aims to restore the Mentawai people's awareness of the richness of their traditions, preserve the Mentawai cultural traditions, in addition to promoting the values of local wisdom of this region to the outside world. 
As a researcher, the proposer feels responsible for the continuity of cultural activities in the Mentawai tribal community, which is very close and strong with the traditions and customs that we have passed down from generation to generation. The existence of global influence causes the Mentawai tribe to lose their identity, connection with indigenous traditions and culture. The Mentawai tribal people are only used as objects which are then taken out of the community without knowing what to do with them. Plus the forced displacement of customary lands, has increased poverty and despair among the Mentawai people. Through this research, the proposer hopes to return the Sikerei tradition as an ancient treatment of the Mentawai tribe to the community again. Foster an understanding that these customs and traditions belong to the Mentawai tribe and are the wealth of Indonesia. As a proposer, I have studied several sciences about cultural preservation.

\section{A. Mentawai Tribe Community in Madobak Village}

The Mentawai Islands Regency is a regency located in the westernmost part of Sumatra Island and is surrounded by the Indian Ocean. The Mentawai Islands Regency was established in April 1999, with the capital city of Tuapeijat, which is one of the regencies in West Sumatra Province with a total area of 6,011.35 km2. The Mentawai Islands Regency consists of four large islands, namely Siberut Island, Sipora Island, North Pagai Island and South Pagai which are inhabited by the majority of the Mentawai tribal community. South Siberut District is divided into several villages; Maileppet, Muara Siberut, Puro, Matotonan and Madobag villages. One of the villages; Madobag Village which is the upstream village of South Siberut District, which has an area of 15,690 $\mathrm{km}^{2}$. The population of Madobag Village is 2755 people. The village of Madobag has a very potential cultural tourism attraction and traditional life (Deki Zulhitra, 2016)

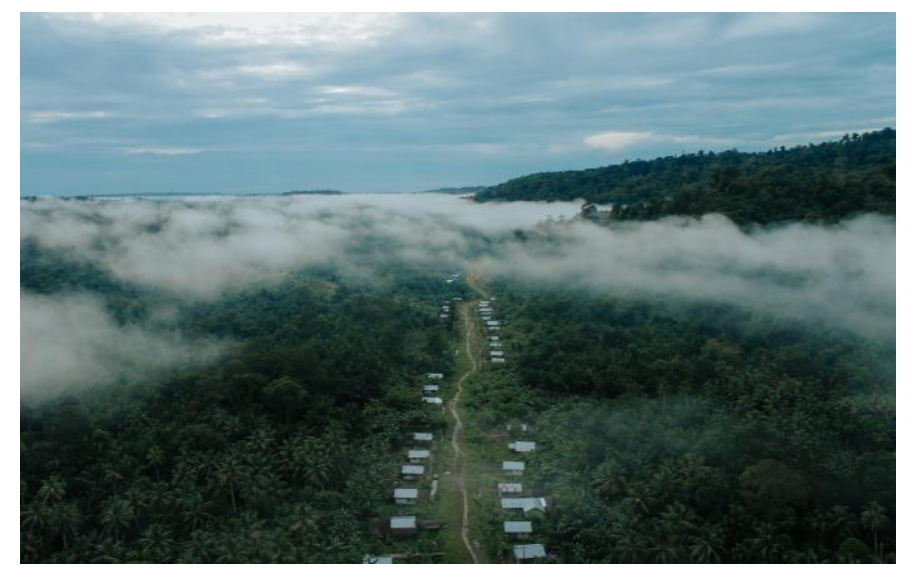

Photo 1

Madobak village seen from above (Documentation By: Ivan Saputra, 2021)

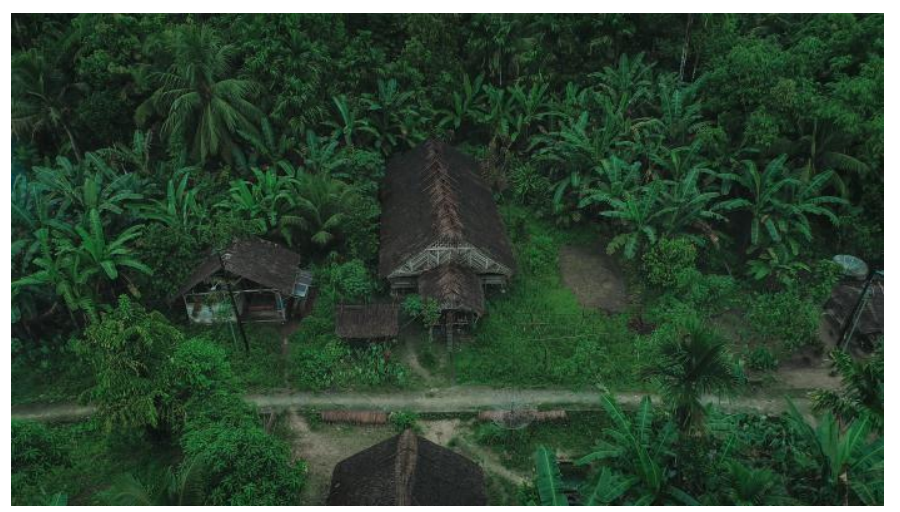

Photo 2

This publication is licensed under Creative Commons Attribution CC BY. 


\section{Housing in Madobak Village seen from above (Documentation By: Ivan Saputra, 2021)}

The people of Madobag Village use the original Mentawai language and maintain the distinctive language of the Mentawai tribe and still use it in daily communication. The people of Madobag Village still hold brotherly ties, in carrying out any activities together, both in village organizational activities, traditional events and farming/gardening. The system is only living equipment in Madobag Village, some of which still use traditional Mentawai equipment, in a positive case the traditional equipment does not damage their environment. The people of Madobag Village still survive from nature, their search system is gardening, farming, and hunting. (Deki Zulhitra, 2016)

\section{B. Uma (Traditional House of Mentawai Tribe)}

Uma in the Mentawai community in value, his position is still the same. Uma is only inhabited by one family head or at most two. The walls of the Uma of the Samoan Bailoi Tribe are covered with planks. But what's interesting is that the plank walls are still being drilled (traditional process). The column (bollard) is divided into two, the main column (uggla) and the regular column. Uggla is taken from the ribbu wood that usually grows in the upper Alimoi area (the name of a river in Matotonan). (Eljihadi Alfin, Widihardjo, 2020)

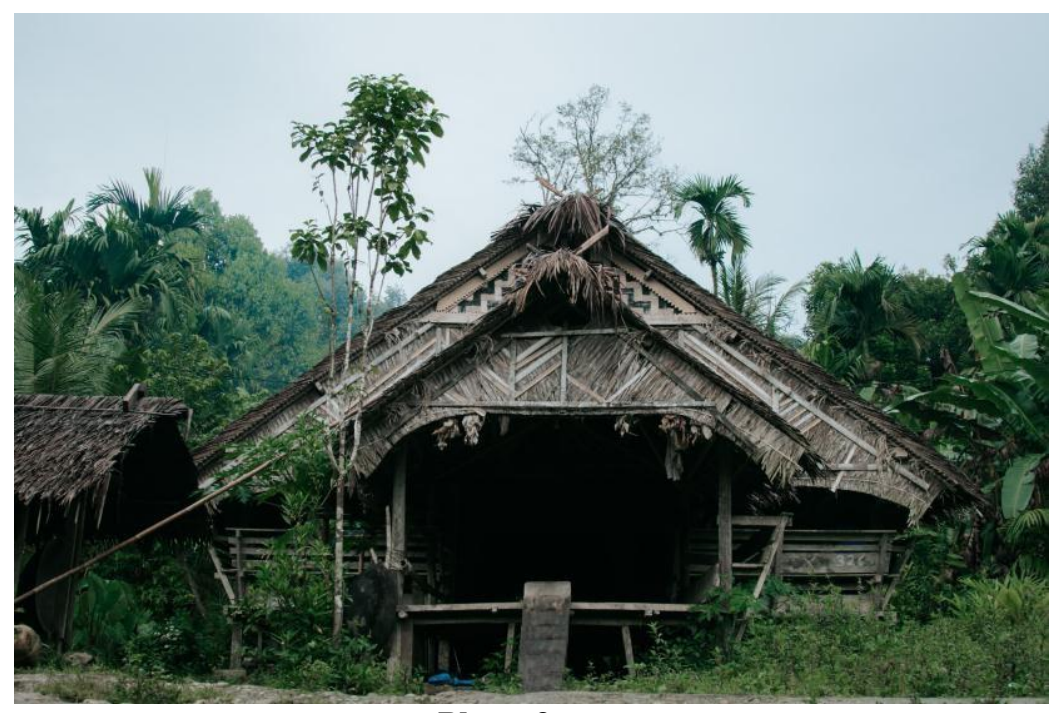

Photo 3

Uma (Mentawai Traditional House in Madobak Village) 


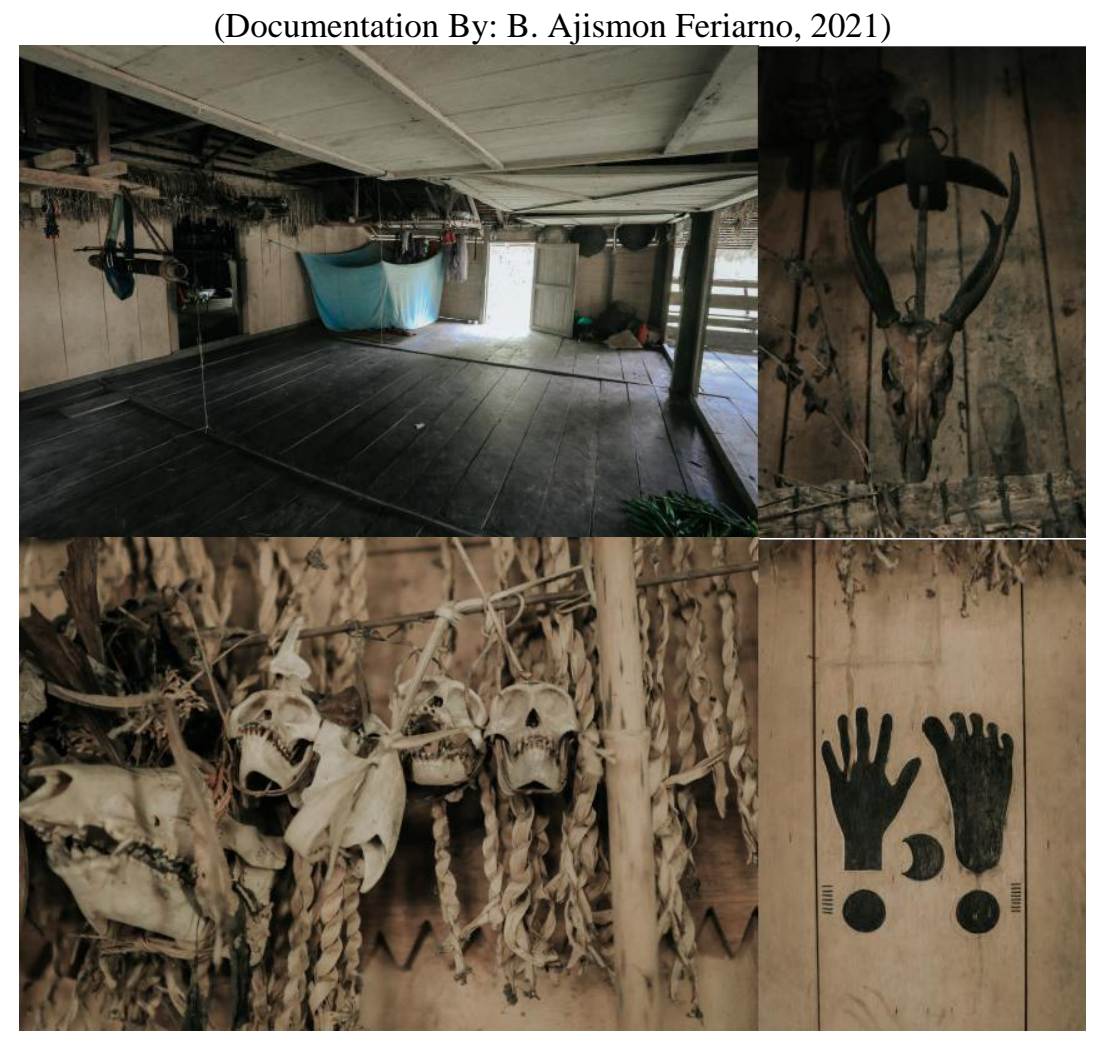

Photo 4

Parts of Uma

(Documentation By: B. Ajismon Feriarno, 2021)

Major milestones can be used up to three times the build of the Uma. The floor pattern in Uma is divided into three, namely left, middle, and right. These three parts are separated by a wooden block called a tubbuk. The right and left parts, which are taken from the ribbing rod, are called aririb. Meanwhile, the middle one is covered by a planed plank, usually taken from taingorut or nakkat wood. The floor is not nailed so it will make a sound when stepped on. (Eljihadi Alfin, Widihardjo, 2020)

\section{Mentawai Tribe Ancient Medicine Ritual}

The discussion in this sub-chapter is how the indigenous Mentawai tribe heals disease and tries to prolong life, the author will dig deeper into the ancient healing rituals of the Mentawai tribe. First, it is worth mentioning that traditional medicine has been developed and relied on by the Mentawai people for thousands of years. It wasn't until 1901 that the first missionaries (August Lett) arrived; and 1954 before the introduction of national programs designed to 'integrate tribal groups into the social and cultural mainstream of the country' - shortly after the Mentawai became part of the State of Indonesia (1950). (Rob, 2014) 


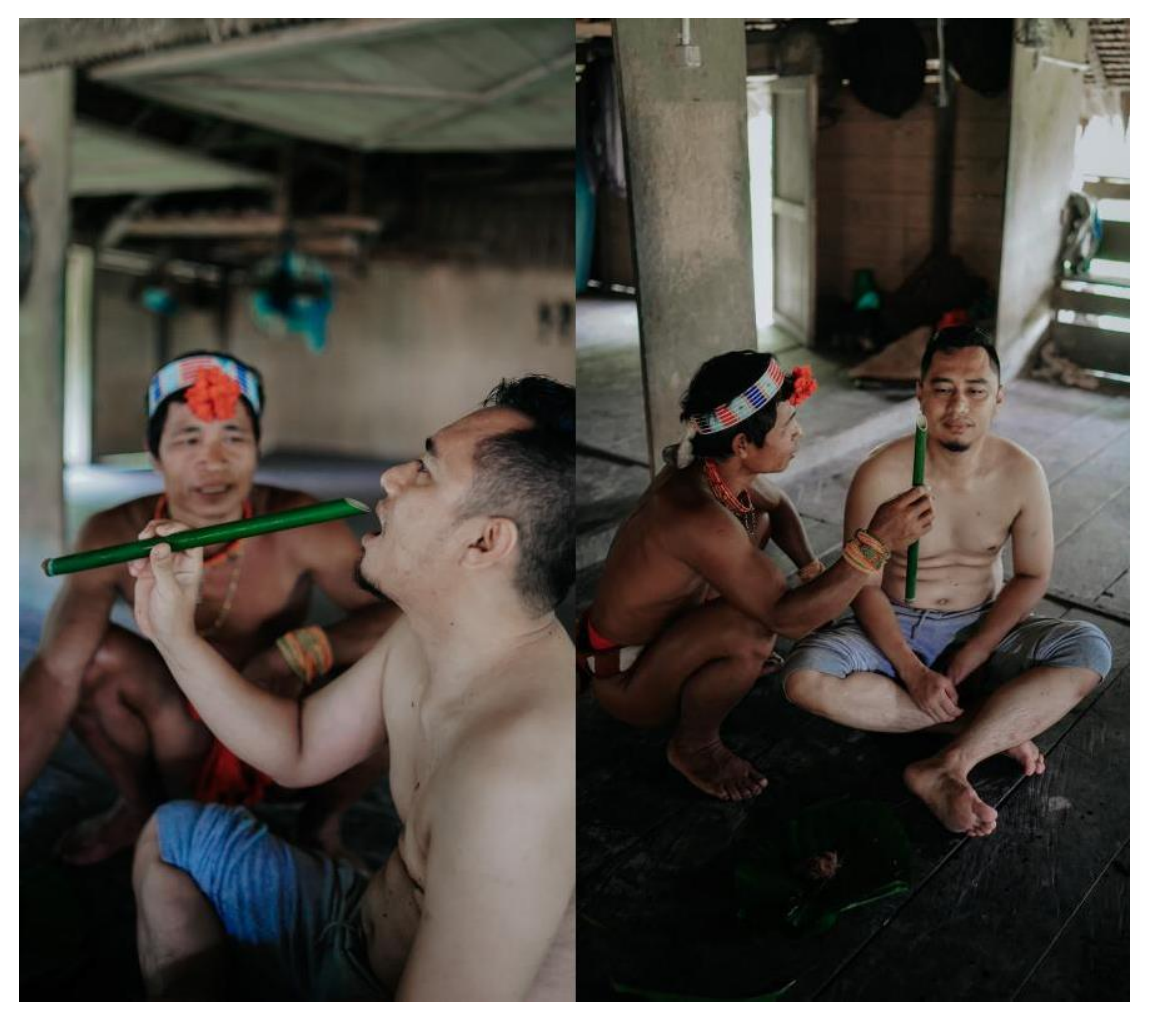

Photo 5

Ritual Treatment By Sikerei (Documentation By: Ivan Saputra, 2021)

The origin of Mentawai medicine actually dates back to the arrival of the first Sikerei. Which, perhaps reflecting the wisdom and foresight of their ancestors, is said to have deterred a little boy named Simaliggai. Like ancient mythology, Simaliggai has an intimate connection with the forest - the boy knows how to hunt, gather, grow, heal, preserve and keep the peace within. Naturally, everyone wanted to know how to do this. (Rob, 2014) 


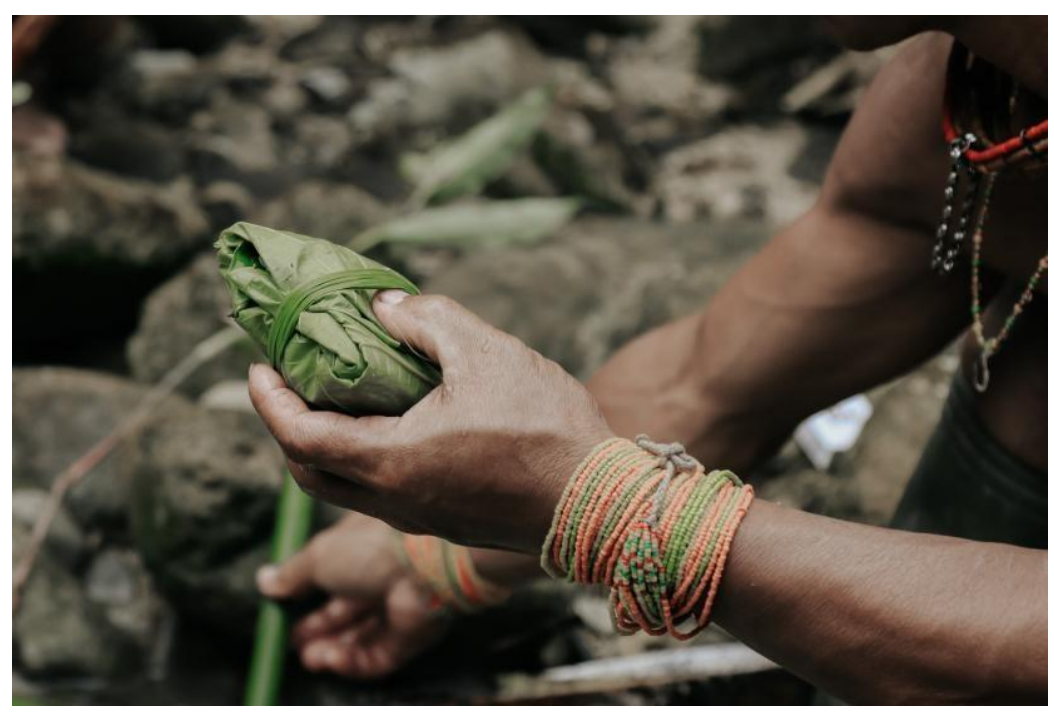

Photo 7

Drug Packaging Process By Sikerei (Documentation By: B. Ajismon Feriarno, 2021)

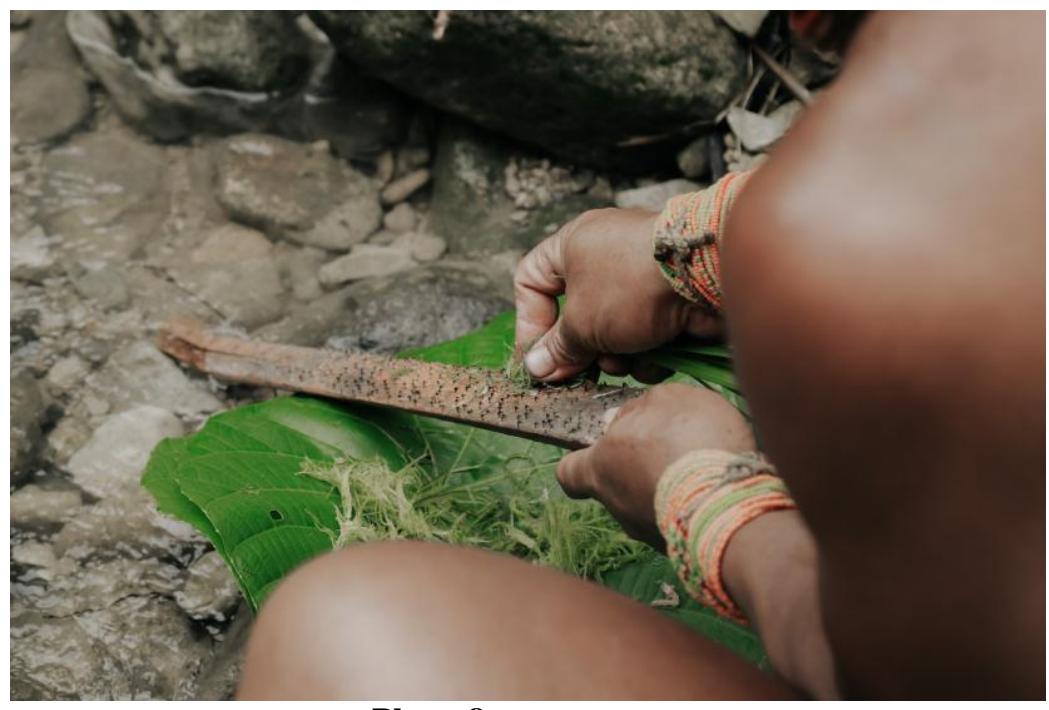

Photo 8

Drug Grating Process By Sikerei (Documentation By: B. Ajismon Feriarno, 2021) 


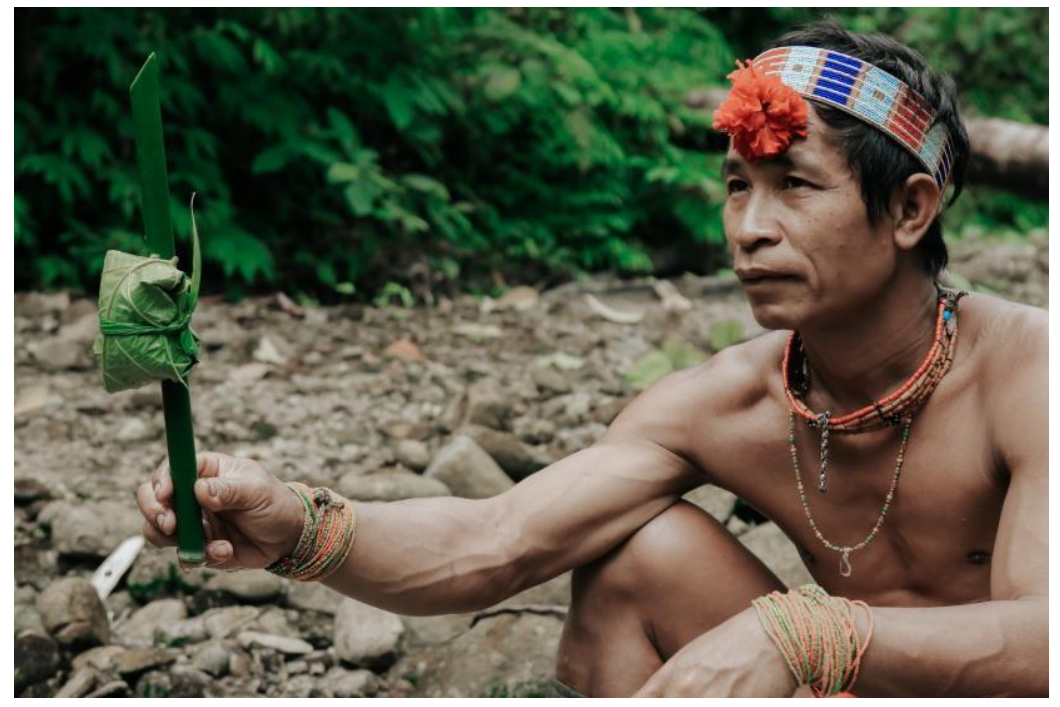

Photo 9

Medicines that have been wrapped by SIkerei (Documentation By: B. Ajismon Feriarno, 2021)

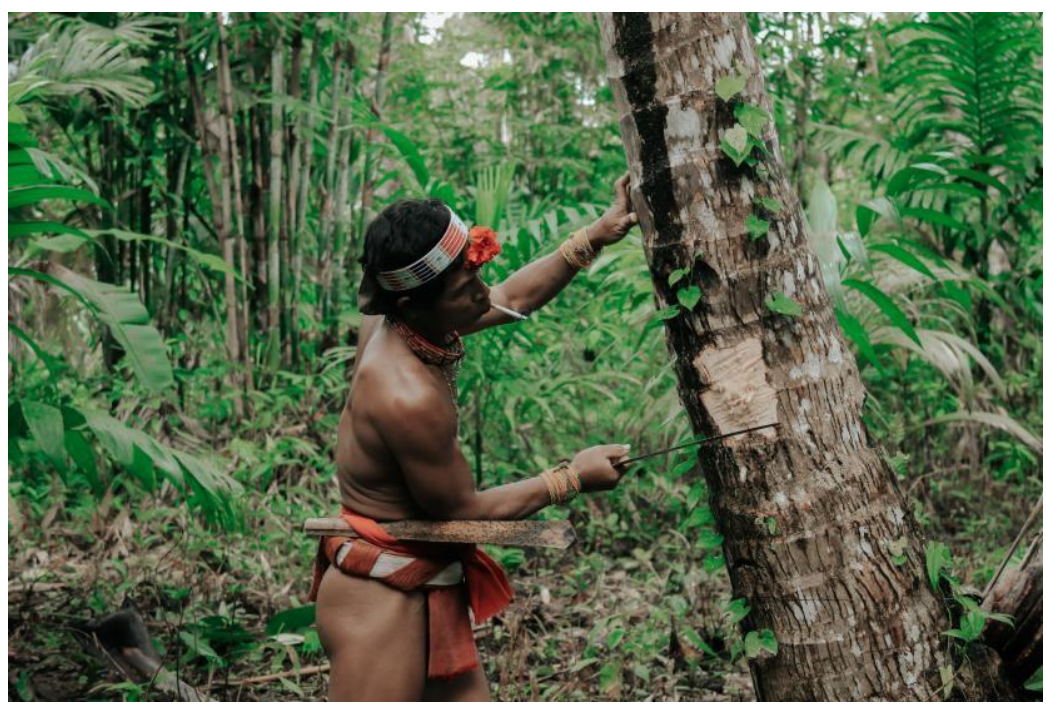

Foto 10

The Process of Taking Medicines on Coconut Trees (Documentation By: B. Ajismon Feriarno, 2021) 


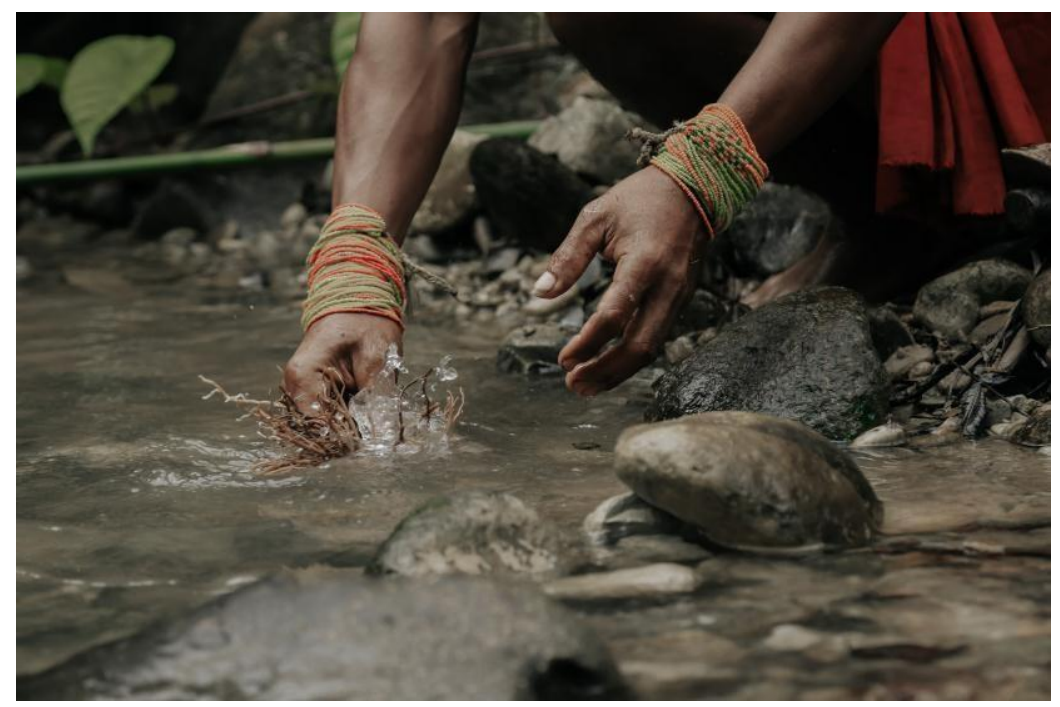

Photo 11

The process of washing drugs taken from plant roots (Documentation By: B. Ajismon Feriarno, 2021)

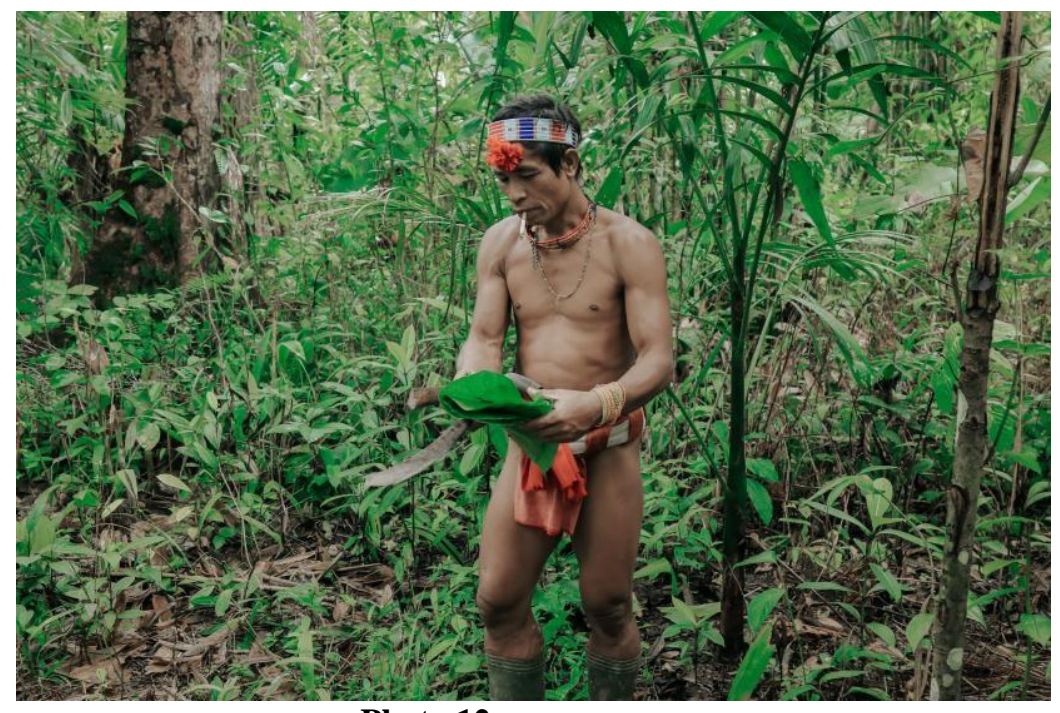

Photo 12

The Process of Collecting Medicines From Leaves (Documentation By: B. Ajismon Feriarno, 2021) 


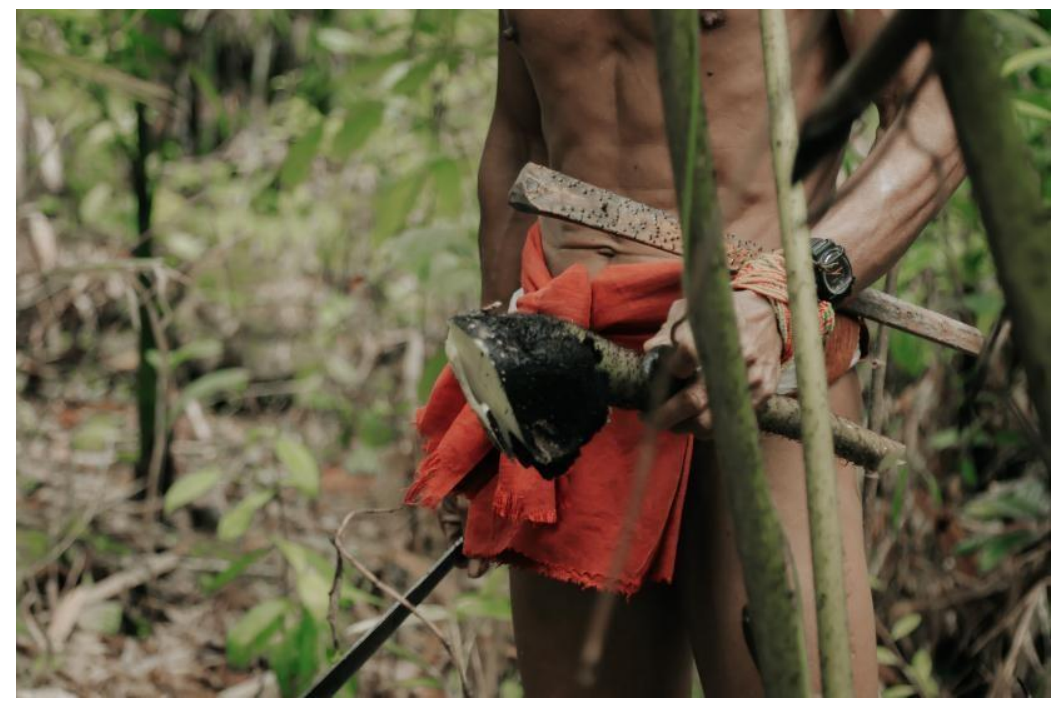

Photo 13

The Process of Taking Medicines From Small Trees (Documentation By: B. Ajismon Feriarno, 2021)

Simaliggai, taking advantage of this luck, decided to teach this knowledge to others and, in doing so, formulated a method called 'Kerei'. Where, following in Simaliggai's footsteps, everyone who learns these Kerei skills will also become educators - devoting their lives to teaching, healing and protecting others. Which has quickly become the most coveted role in traditional Mentawai society, it does offer some insight into the origins of cultural values and success in maintaining their existence. Basically Sikerei is the backbone of Mentawai culture and sustainability - a community figure who becomes the foundation of the entire community for healing, guidance, comfort, certainty, protection and security. Providing medical services is certainly one element but it is fair to say that it goes much deeper. To provide context, I thought I would share with you an interesting quote on Public Health from the Mentawai Indigenous Peoples Research Report document: (Rob, 2014)

Access to health care on Siberut Island has not changed since 1998 when Cheeseman and Kramer conducted the health study 'Incidence of Illness among Mentawai People on Siberut Island', as their description of modern health care facilities on the island remains valid: 'Currently there are only one (operational) government-run public health clinic (puskesmas) in each of the two district cities, Muara Siberut and Muara Sikabaluan. A Puskesmas has been built in every PKMT village (over 60 settlements) across the island but, with medical staff concentrated in only two district towns, neither of the villages is actually operational. (Rob, 2014)

\section{Forests and Hunting for the Mentawai Tribe}

The activity of hunting animals in the forest by means of archery has a deep meaning for the Mentawai people in the Mentawai Islands, West Sumatra. The main purpose of hunting is to meet daily needs, especially food. However, there are also hunting and archery traditions that are carried out as a means of proving love for the tribe or as a prerequisite in custom. For game that is usually in a tree, for example, the archer will use a pointed arrow and a thick poison that is dried at the end of the arrow. Meanwhile, the use of arrows using long iron plates to hunt land animals such as deer (tunung). The use of arrows with an elongated iron plate is intentionally made to make wider cuts on the body of the prey animal. The goal is that the drops of the prey's blood can provide clues for the hunter to follow in his footsteps. 


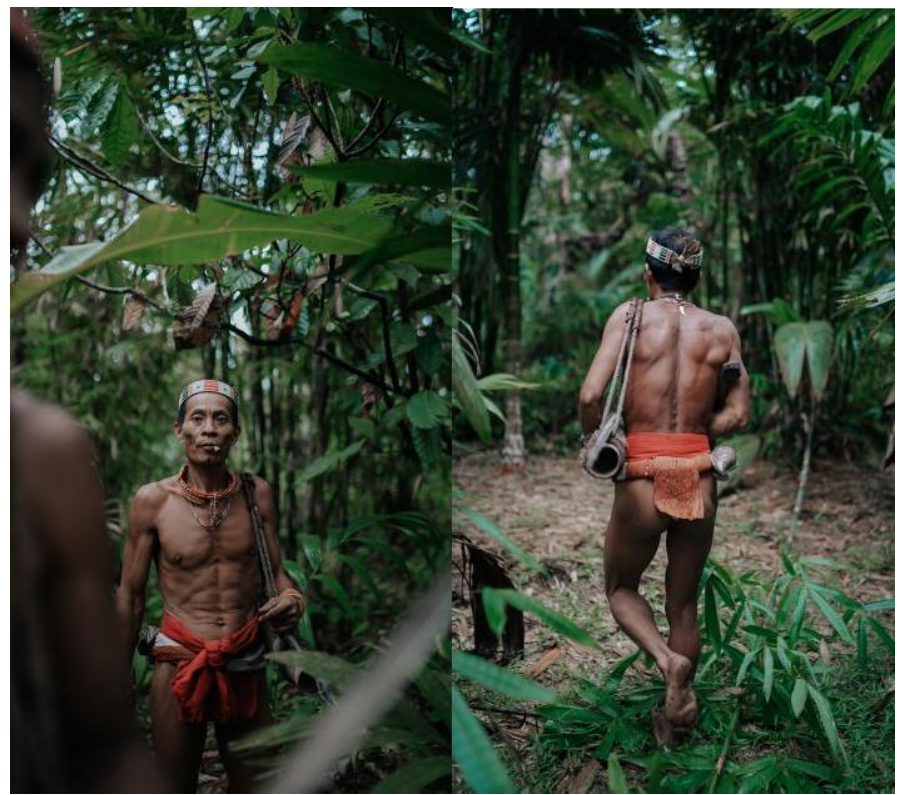

Photo 13

Hunting Preparation By Sikerei (Documentation By: Ivan Saputra, 2021)

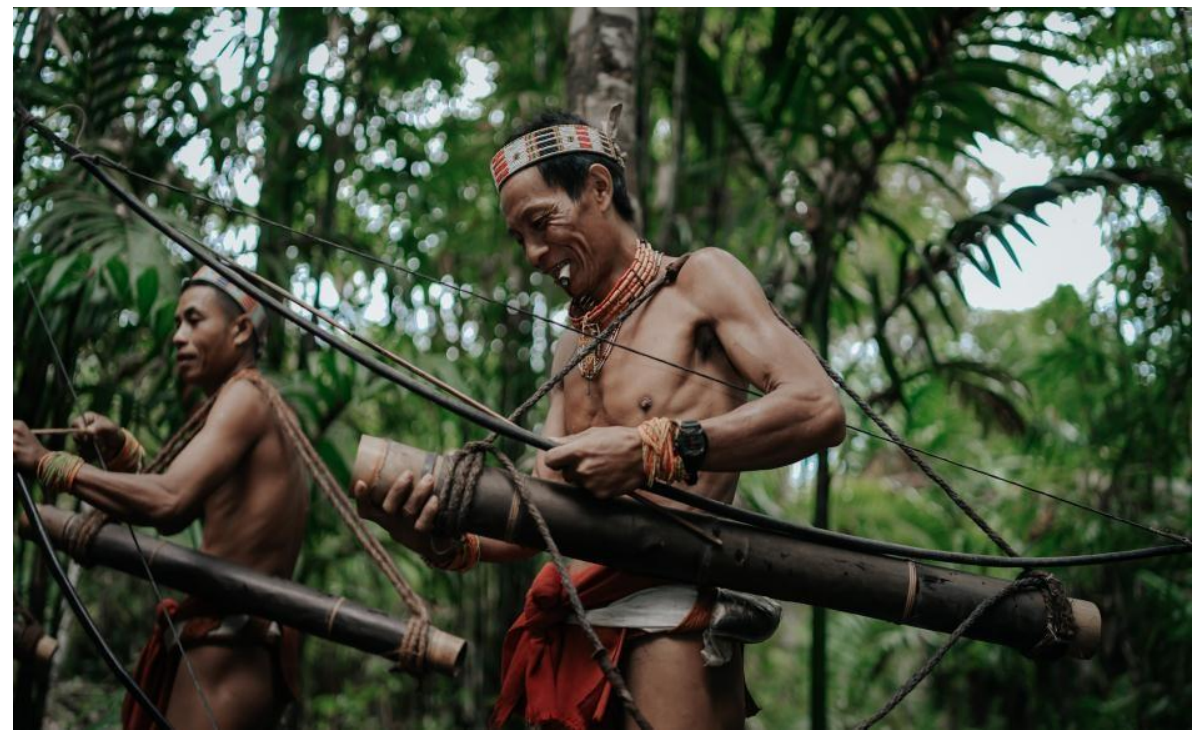

Photo 14

Archery Preparation Hurry up (Documentation BY: Ivan Saputra, 2021) 


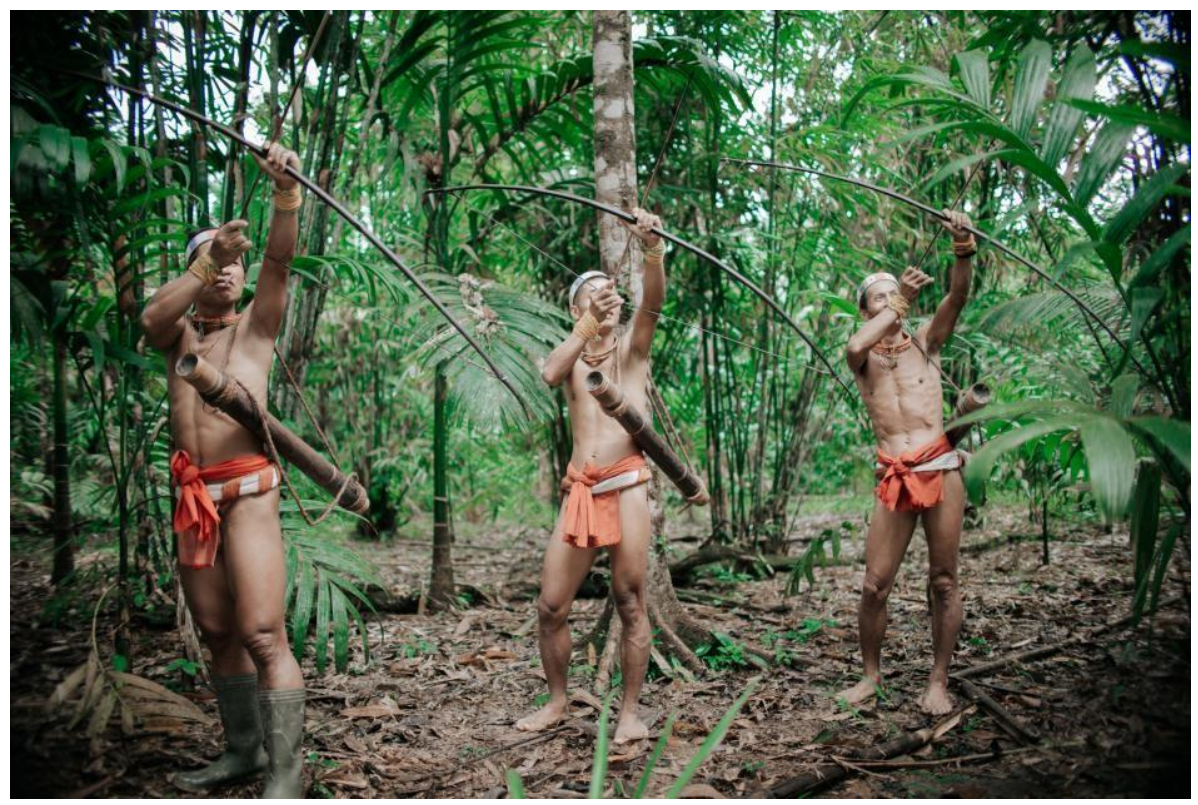

Photo 15

\section{Archery Procession (Hunting By Sikerei) (Documentation By: Yuli Hendra, 2021)}

\section{E. Sikerei in the Perspective of the Postmodern Era of Performing Arts}

\section{Turuk Lagai}

Turuk Laggai dance is a dance of the Mentawai tribal community. Its existence is not as popular as other dances in West Sumatra such as the Plate Dance, Pasambahan or Payung dance, but for the Mentawai people, its existence is always preserved as a Historic Culture. As we know that, Mentawai and Nature are two elements that cannot be separated. The majority of traditions and customs there must be combined with things that smell natural, not to mention the property used in this Turuk Laggai Dance. Here, the full review for all of you. This dance from Mentawai is one of the dance arts that has a strong bond with nature. This can be illustrated by the movement of the Turuk Laggai Dance which is widely adopted from the surrounding environment, precisely imitating the movements of animals. Based on several studies, this dance appeared around the 17th century, meaning that it is more than 300 years old. (Nabila Zahra, 2020)

Since ancient times, the Mentawai people have mostly depended on hunting rather than fishing. Thus, the movements in this dance are inspired by the movements of the animals they encounter in the forest when hunting. Since the beginning of its appearance, the Turuk Laggai Dance has been part of the treatment ceremony, which involves a shaman (Sikerei). The procession is carried out at night, because they believe that communication between the supernatural spirit and the Sikerei will run more smoothly. Along with the development of the times, finally this dance is now used as entertainment. (Nabila Zahra, 2020) 


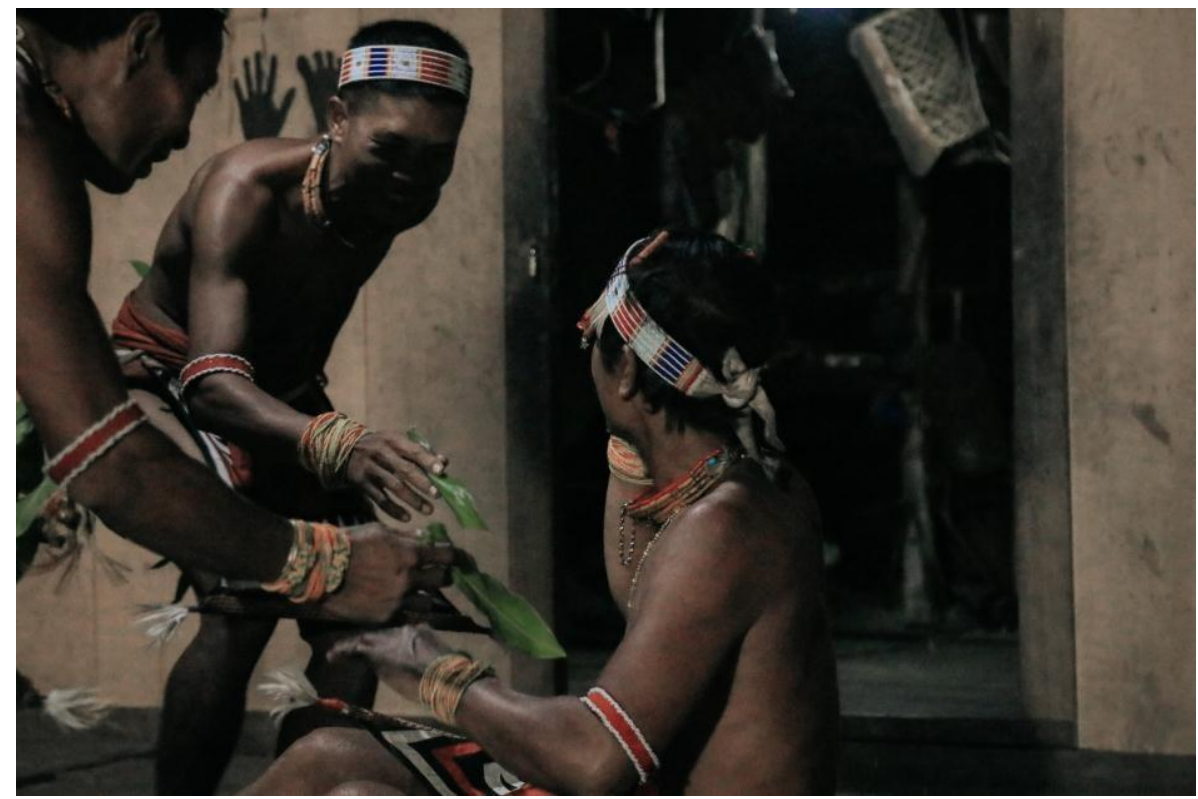

Photo 16

Movements in the Turuk Laggai dance (Documentation By: Yuli Hendra, 2021) 

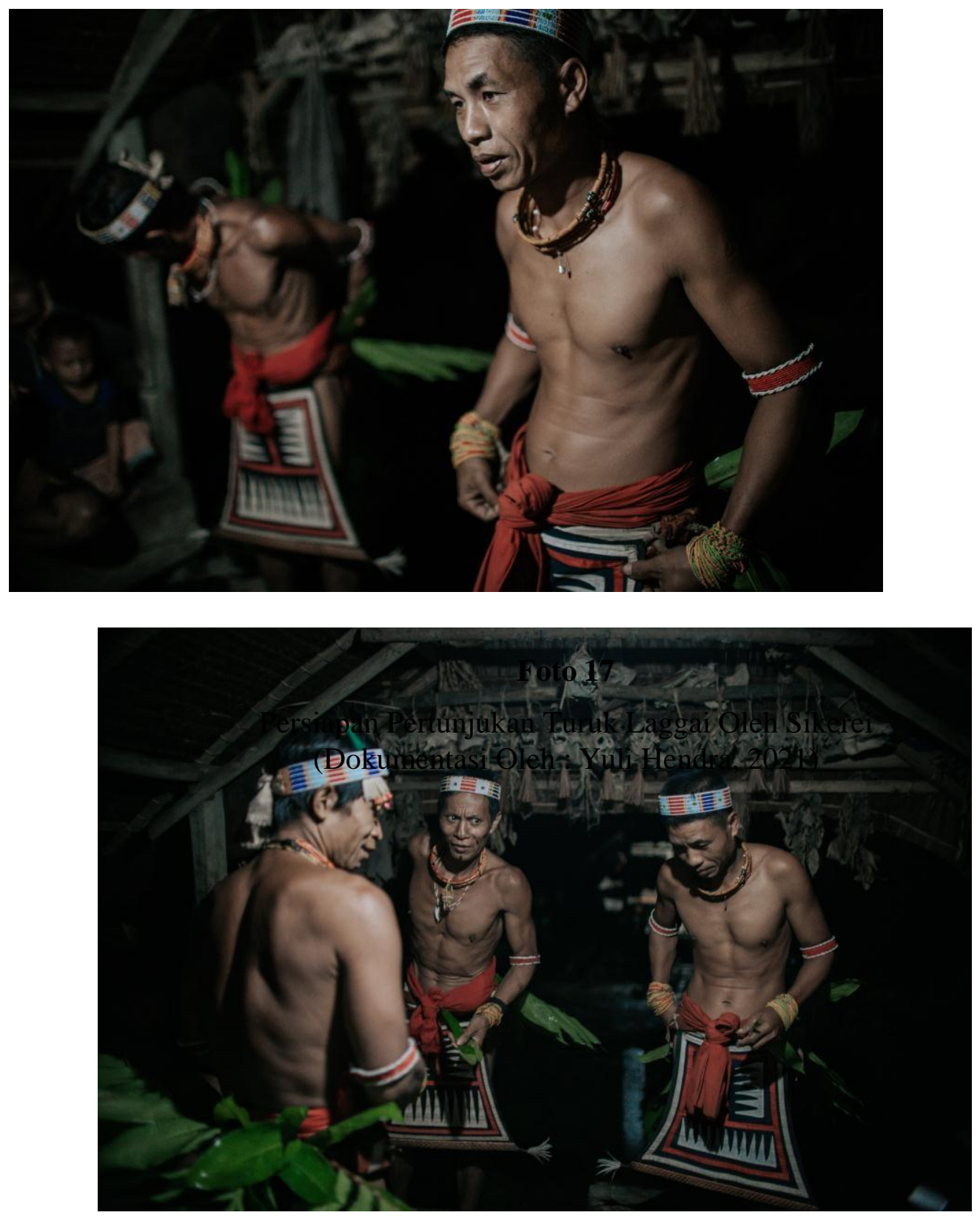

Photo 18

Use of Leaves in Performance Preparation (Documentation By: Yuli Hendra, 2021) 


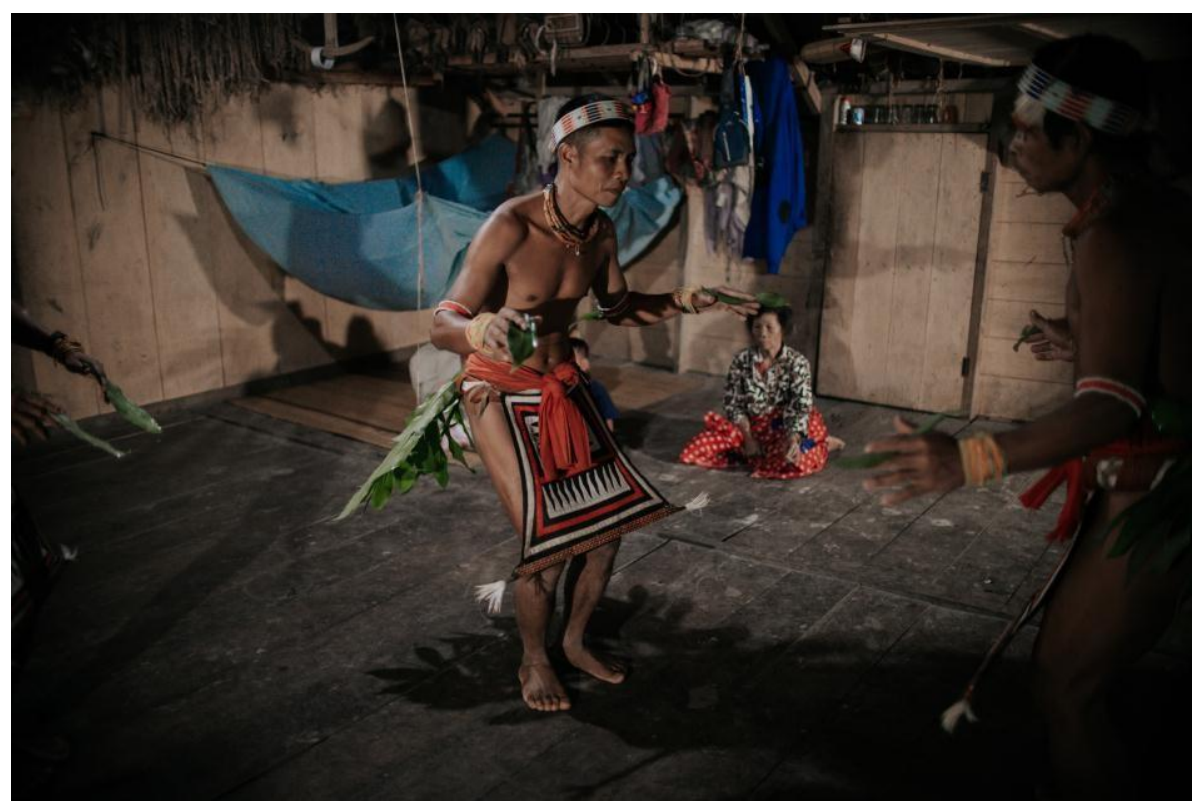

Photo 19

One of the Movements in the Turuk Laggai Dance by Sikerei (Documentation By: Yuli Hendra, 2021)

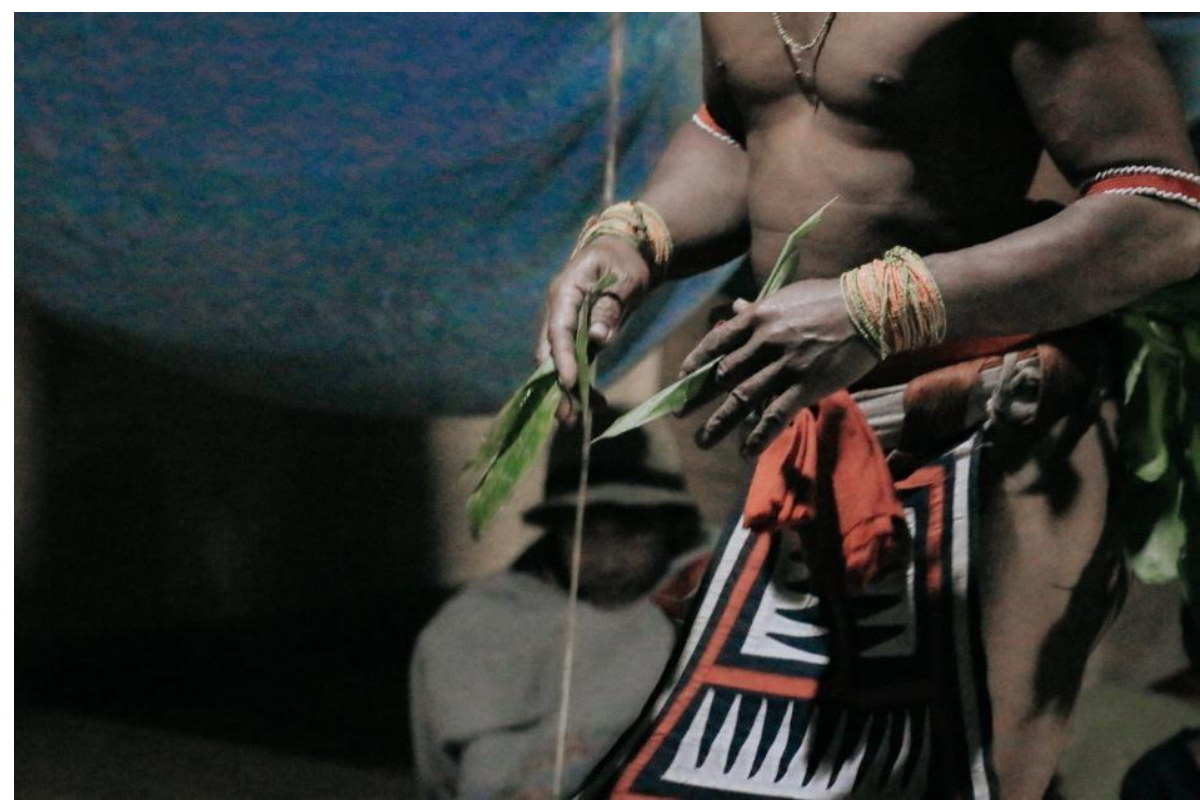

Photo 20

Hand Gestures In Turuk Laggai Dance By Sikerei (Documentation By: Yuli Hendra, 2021) 


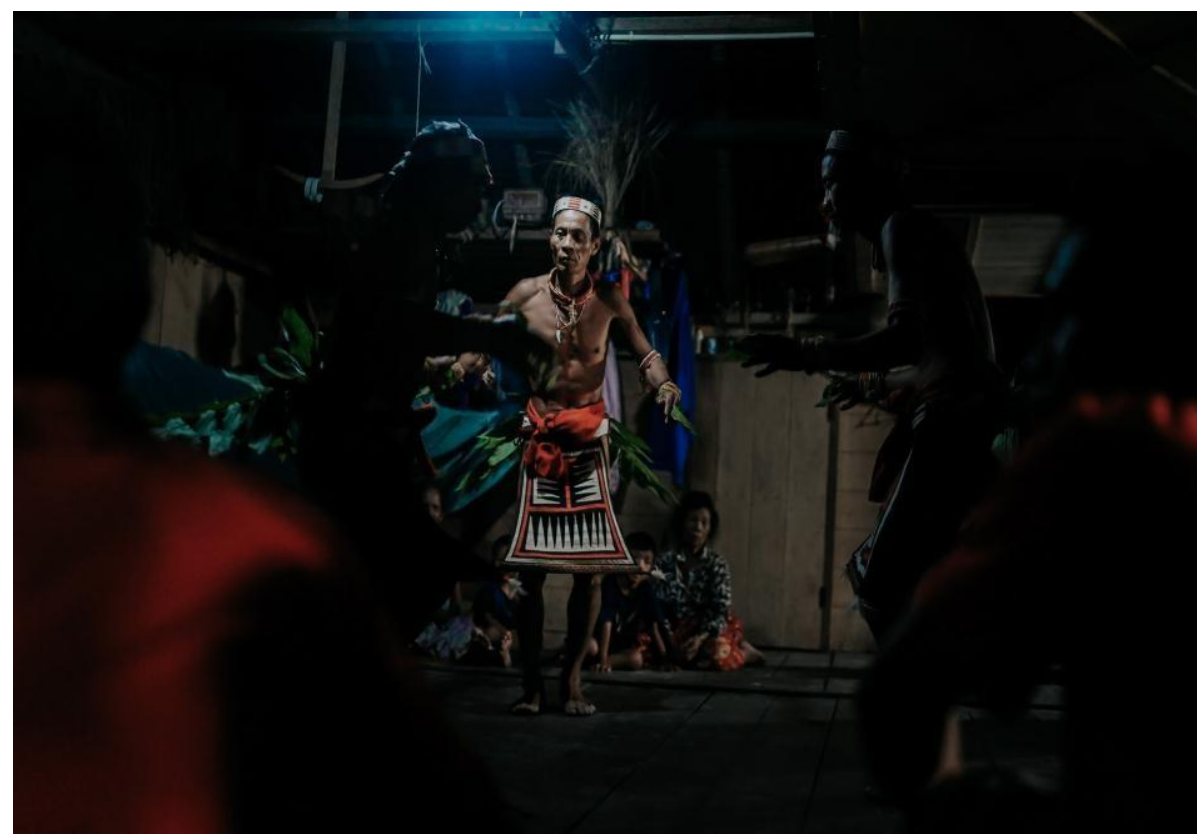

Photo 21

Characterizations in the Turuk Lagai Dance (Documentation By: Ivan Saputra, 2021)

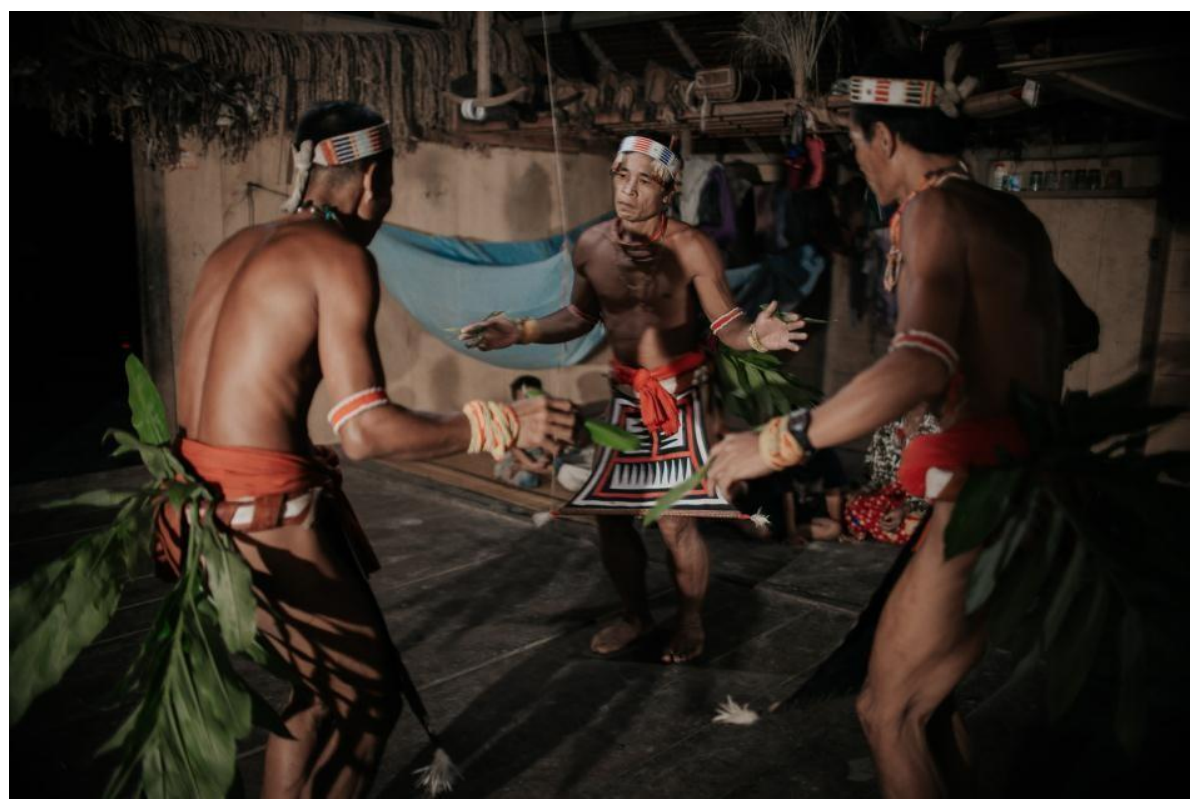

Photo 22

Circular Movement as a Ritual Symbol (Documentation By: Yuli Hendra, 2021) 


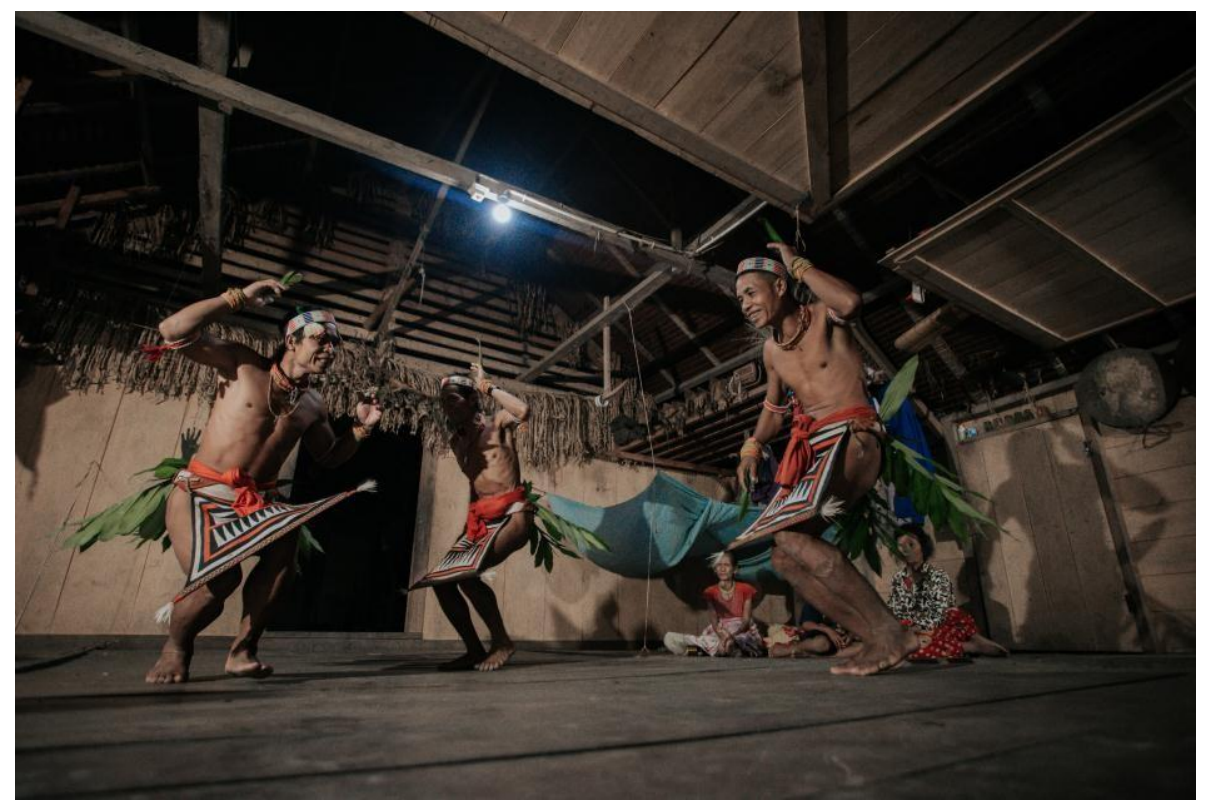

Photo 23

Footsteps as a Ritual Symbol (Documentation By: Yuli Hendra, 2021)

Apart from having a historical background, all traditional dances must have a function and purpose. The purpose of the Turuk Langgai Dance is to entertain the supernatural spirit, so that the supernatural spirit does not leave what is in the patient's body. Because if the spirit goes, then the patient will die. In addition, this unique Mentawai dance also functions as a transmitter of noble values for all communities, such as the values of unity, prosperity, love and peace between tribes. And also, it is always preserved so that local culture that is already rare is not lost to time. The musical instrument that accompanies the Turuk Laggai Dance is the Tuddukat, one of the percussion instruments as a messenger in the Mentawai tribe. When this tool is hit, the Sikerei / dancers will tiptoe on their feet, the head looks up, the body is bent and the hands holding the leaves will begin to sway. His feet were also pounded on the floor rhythmically, producing a regular rhythmic sound. All the dancers will circle and sometimes chase each other. The screeching of Urai (singing) will also be heard from time to time from the mouths of the Sikerei. (Nabila Zahra, 2020)

\section{REFERENCES}

[1] Agger, Ben. 1992, Culture Studies as Critical Theory. London: The Falmer Press. Barker, Chris. 2005, Cultural Studies: Teori dan Praktik. (Terjemahan). Yogyakarta:PT Bentang Pustaka.

[2] Bambang Rudito, Dan Sunarseh (2013). Masyarakat dan Kebudayaan Mentawai.

[3] Padang: Dinas Kebudayaan dan Pariwisata Provinsi Sumatra Barat UPTD Museum Nagari.

[4] Cangara, Hafied. 2000, Pengantar Ilmu Komunikasi. (Cet. kedua), Jakarta: PT. Rajagrafindo.

[5] Du Gay, Hall, Janes, Mackay, and Negus. 1997 Introduction Doing Cultural Studies: The Story of the Sony Walkman. Sage Publications (in association with the Open University)

[6] Ernawati, Tarida (ed) (2015). Upacara Adat Mentawai. Padang: Yayasan Citra Mandiri Mentawai.

[7] Gregor. 2008, Ketika Sejarah Berseragam: Membongkar Ideologi Militer dalam Menyusun Sejarah Indonesia, Yogyakarta: Syarikat.

[8] Hauser, Arnold. 1982, The Sociology of Art, Jakarta: Balai Pustaka.

[9] Hadi, Sutrisno dalam Sugiyono. 2007, Metode Penelitian Kuantitatif, Kualitatif dan R\&D, Bandung,: Alfabeta.

[10] J maquet. 2000, The Sociology of Knowledge, Jakarta: Gramedia.

[11] Kraus, Richard. 1969, "Histori Of The Dance In Art And Education", New Jersey: Prentice Hall, Inc, Englewood Cliffs.

[12] Lewis A. Coser, 1977"Auguste Comte: The Law of Human Progress," in Masters of Sociological Thought: Ideas in Historical and Social Context (Harcourt,)

[13] Lynch, Kevin. 2002, The Image of the City, Jakarta: Gramedia Pustaka Utama Moleong, Lexy J. 1999, Metodologi Penelitian Kualitatif, Bandung: Remaja Rosdakarya.

[14] Manfred Zahnd. 1999, Badminton: Was heisst Handlungsorientierung, Jakarta: Gramedia Pustaka Utama

[15] Malinownsky. 2008. Argonauts Of The Western Pacific (Studies in Economics and Political Science), Jakarta: Gramedia.

[16] Mike Featherstone,Mike Hepworth,Bryan S. Turner. 1991, The Body: Social Process and Cultural Theory, London: u.a. Sage.

[17] Nettl, Bruno. 1983, The Study Ethnomusicology: thirty-one issue and concept, University Of Illinois press, United State.

[18] Philip Kotler, Donald H. Haider, Irving J. Rein. 2002, Marketing Places, Jakarta: Gramedia Pustaka Utama 
ISSN 2250-3153

[19] Rudito, Bambang (2013). Bebetei Uma Kebangkitan Orang Mentawai: Sebuah Etnografi. Yogyakarta: Gading

[20] Ritzer, George, Douglas J. Goodman, 2010, Teori Sosiologi Modern, edisi ke enam, Jakarta: Kencana Media Group

[21] Ritzer, George. 2006, Teori Sosial Postmodern. (Terjemahan). Yogyakarta: Kreasi Wacana

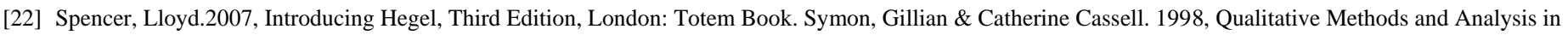

[23] Organizational Research. A Practical Guide. New Delhi: Sage.

[24] Storey, John. 2004, Teori Budaya dan Budaya Pop: Memetakan Lanskap Konseptual Cultural Studies. (Terjemahan). Yogyakarta: CV. Qalam.

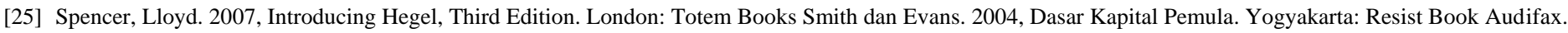

[26] 2006, Imaging Lara Croft: Psikosemiotika, Hiperealitas, dan Simbol-simbol Ketaksadaran. (kata pengantar: Yasraf Amir Piliang). Bandung: Jalasutra.

[27] Van Peursen. 1988, Orientasi di alam filsafat: sebuah pengantar dalam permasalahan filsafat, Jakarta: Gramedia.

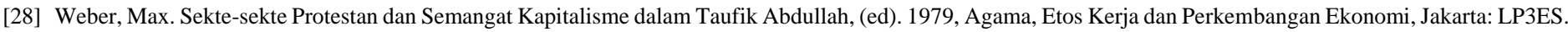

[29] Warisan budaya tak benda di [nama tempat]. Balai Pelestarian Nilai Budaya Padang (Indonesia), (edisi ke-Cetakan pertama). Padang, Sumatra Barat

[30] Willian Chang.2001" Moral lingkungan hidup"Kanisius, Jakarta.

\section{AUTHORS}

First Author - Hendra Nasution, S.Sn., M.Sn, Indonesia Art Institute of Padangpanjang

Second Author - Ezu Oktavianus S.Sn., M.Sn, Indonesia Art Institute of Padangpanjang

Third Author - B Ajismon Feriarno, Indonesia Art Institute of Padangpanjang, ehen_exel@ rocketmail.com 